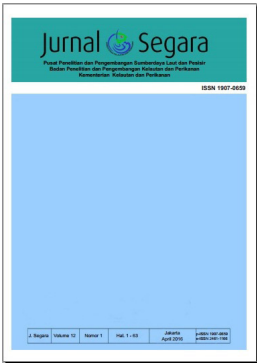

JURNAL SEGARA

http://ejournal-balitbang.kkp.go.id/index.php/segara

ISSN : 1907-0659

e-ISSN : 2461-1166

Nomor Akreditasi: 766/AU3/P2MI-LIPI/10/2016

\title{
GEOMORFOLOGI TERUMBU KARANG DAN HABITAT BENTIK GUGUSAN PULAU BIAWAK, INDRAMAYU: INTEGRASI STUDI CITRA SATELIT DAN SEDIMEN PERMUKAAN
}

\section{CORAL REEF GEOMORPHOLOGY AND BENTHIC HABITAT OF THE BIAWAK ISLANDS, INDRAMAYU: AN INTEGRATED SATELLITE IMAGE AND SURFACE SEDIMENT STUDY}

\author{
Tubagus Solihuddin"1), Dwi Amanda Utami' ${ }^{2,3)}$, August Daulat ${ }^{1)}$, Agustin Rustam¹) \\ 1) Pusat Riset Kelautan, Kementerian Kelautan dan Perikanan, Jakarta, Indonesia 14430 \\ ${ }^{2)}$ Pusat Riset Geoteknologi, Lembaga IImu Pengetahuan Indonesia, Bandung, Indonesia 40135 \\ ${ }^{3)}$ Energy and Mineral Resources Group, Geologische Institute, RWTH Aachen University, Germany
}

Diterima: 6 Januari 2020; Diterima Setelah Perbaikan: 22 Juni 2020; Disetujui Terbit: 5 Agustus 2020

\begin{abstract}
ABSTRAK
Gugusan Pulau Biawak yang terletak di kawasan perairan Laut Jawa saat ini diprioritaskan untuk wilayah konservasi keanekaragaman hayati laut. Deskripsi tentang zona geomorfologi dan habitat bentik terumbu karang serta distribusi sedimen permukaan adalah salah satu informasi penting untuk mendukung kebijakan konservasi, walaupun hal tersebut sering luput dari perhatian para peneliti dan pengambil kebijakan. Studi ini memberikan gambaran geomorfologi terumbu karang dan habitat bentik serta karakteristik sedimen permukaan dari tiga pulau di gugusan Pulau Biawak, Indramayu beserta faktor pengendali dan sifat khususnya melalui studi integrasi citra satelit dan analisis sedimen permukaan. Zona rataan terumbu menunjukkan dominasi endapan pasir dan fragmen koral serta kalkareus alga kecuali di Pulau Biawak banyak ditumbuhi Halimeda. Koloni terumbu karang tumbuh sumbur di zona lereng terumbu pada sisi bagian barat pulau pada kedalaman hingga $5 \mathrm{~m}$. Tekstur sedimen menunjukkan dominasi pasir kasar tanpa pola gradasi seiring dengan perubahan geomorfologi dan habitat bentik. Komposisi sedimen didominasi oleh komponen bioklastik, yang terdiri atas koral dan moluska sebagai dua komponen utama.
\end{abstract}

Keywords: Geomorfologi, habitat bentik, sedimen permukaan, konservasi, Pulau Biawak.

\begin{abstract}
Biawak Island Group in the Java Sea has currently been prioritized for marine biodiversity conservation. Description of geomorphic zones and benthic habitats of coral reefs and surficial sediment distribution is one of the essential information to support conservation policies, but such has received little attention both from reef researchers and policy makers. This study provides an overview of the coral reef geomorphology and associated benthic habitats as well as the characteristics of surficial sediments of the three islands in the Biawak Island Group, Indramayu along with their controlling factors and specific characteristics through the integrated study of satellite imagery and surficial sediment analysis. The reef flat zones show the dominance of sand deposits and coral fragments as well as calcareous algae with the exception of Biawak Island, occupied by Halimeda. Prolific coral reef colonized the reef slope zone on the western side of the island at depths of up to 5 $\mathrm{m}$. Sediment texture shows the dominance of coarse sand with no grading patterns concerning geomorphological and benthic habitat succession. Sediment composition is dominated by bioclastic components, consisted of coral and mollusks as the two highest components.
\end{abstract}

Keywords: Geomophology, habitat benthic, surficial sediment, conservation, Biawak Island.

Corresponding author:

Jl. Pasir Putih I Ancol Timur, Jakarta Utara 14430. Email: solihuddin@gmail.com 


\section{PENDAHULUAN}

Gugusan Pulau Biawak secara geografis terletak pada $5^{\circ} 87^{\prime} \mathrm{LS}$ dan $108^{\circ} 4^{\prime} \mathrm{BT}$ yang merupakan wilayah administrasi Kabupaten Indramayu Jawa Barat serta terletak di Laut Jawa sekitar $50 \mathrm{~km}$ dari Karangsong, Indramayu. Pulau-pulau yang termasuk gugusan Gugusan Pulau ini diantaranya adalah Biawak, Gosong, dan Candikiang (Gambar 1). Gugusan Pulau Biawak saat ini menjadi prioritas untuk kawasan konservasi keanekaragaman hayati laut terutama terumbu karang sebagai konsekuensi dari rencana penetapan Kawasan Konservasi Perairan Daerah (KKPD). Kepedulian untuk melindungi keanekaragaman hayati laut dan sumber daya alam di Gugusan Pulau Biawak serta untuk memonitor perkembangan wilayah ini telah tercantum dalam dokumen nasional pengelolaan dan perencanaan kawasan konservasi perairan melalui Undang-undang No. 31 Tahun 2004 jo UU 45 Tahun 2009 tentang perikanan, serta Undang-undang No. 27 Tahun 2007 jo Undang-undang No 1. Tahun 2014 tentang pengelolaan wilayah pesisir dan pulau-pulau kecil dan diperkuat melalui Peraturan Pemerintah No. 60 Tahun 2007.

Gugusan Pulau Biawak, khususnya Pulau Biawak telah digunakan untuk kegiatan pariwisata bahari termasuk wisata pantai, snorkeling, dan menyelam disamping aktivitas lainnya seperti wisata religi dan fasilitas navigasi transportasi laut (Purba \& Harahap, 2013). Terlepas dari kenyataan bahwa penggunaan saat ini hanya mengakibatkan gangguan antropogenik terbatas, pertumbuhan kegiatan wisata bahari selama beberapa tahun mendatang berpotensi mengganggu lingkungan perairan Gugusan Pulau Biawak. Selain itu, ancaman terkait aktivitas nelayan seperti jaring ikan dan jangkar perahu juga perubahan iklim seperti kenaikan suhu permukaan, pengasaman laut, dan prediksi peningkatan intensitas gelombang badai perlu segera diantisipasi untuk melindungi ekosistem pesisir di Gugusan Pulau Biawak, terutama terumbu karang (Sunarto et al., 2013)

Hingga saat ini, studi tentang pemetaan habitat bentik terumbu karang dari perspektif geomorfologi masih sangat terbatas di Indonesia (Solihuddin et al., 2019). Studi terumbu karang umumnya masih difokuskan pada studi biologi terkait dengan jenis dan distribusi biota serta studi ekologi terkait dengan hubungan timbal balik antara ekosistem terumbu karang dengan lingkungan perairan. Sementara, studi tentang geomorfologi terumbu karang dan habitat bentik masih sangat terbatas, khususnya di Gugusan Pulau Biawak. Di sisi lain, ada kebutuhan untuk lebih memahami informasi tersebut serta penggunaannya dalam mengembangkan dan menerapkan kebijakan pengelolaan dan konservasi perairan (Asriningrum, 2011).

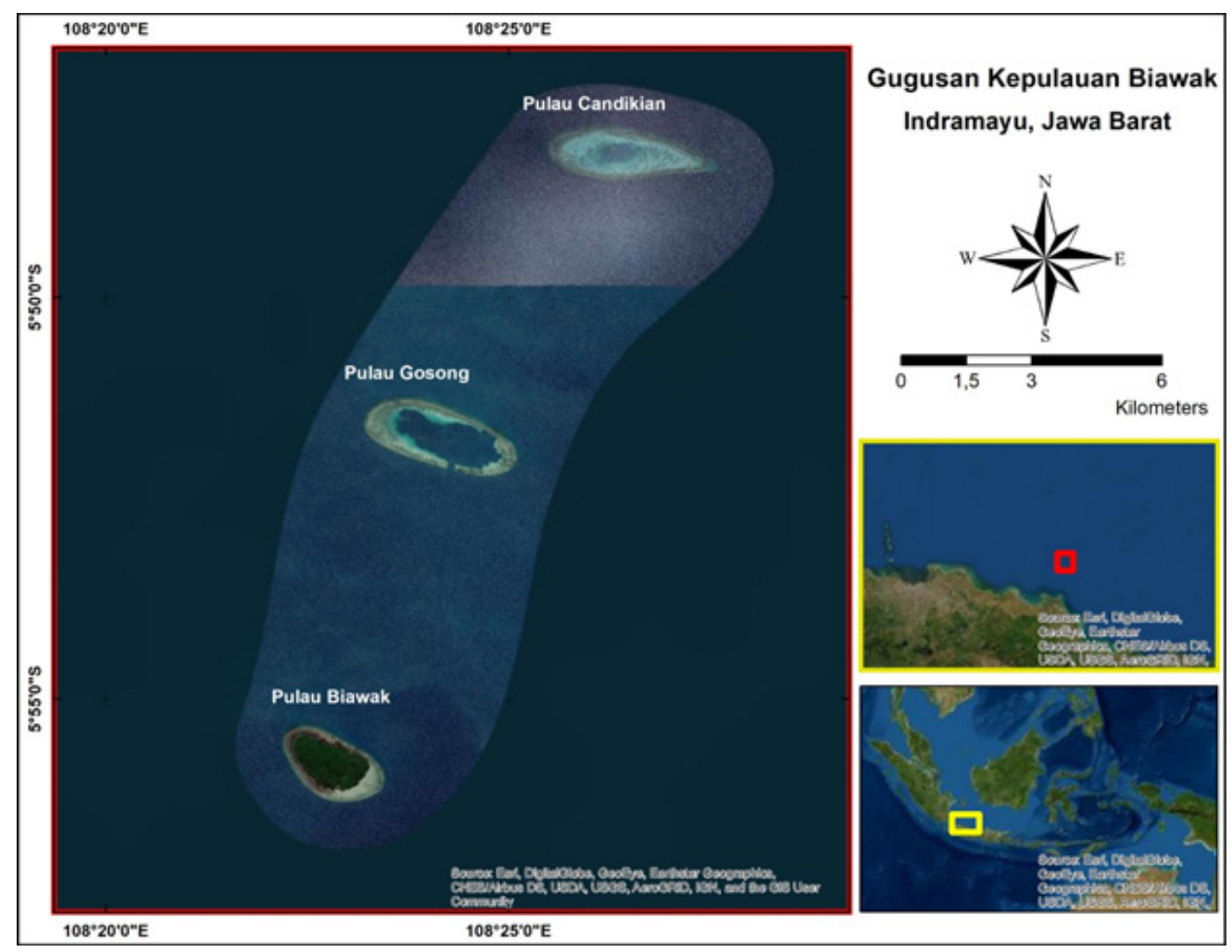

Gambar 1. Gugusan Pulau Biawak yang terletak di lepas pantai Kabupaten Indramayu, Jawa Barat berorientasi relatif timur-barat (Sumber: Citra Satelit Sentinel-2A RGB 432). 
Pemetaan geomorfologi terumbu karang memberikan informasi penting terkait dengan jenis substrat, komunitas karang, dan habitat bentik yang menjadi kontrol utama terhadap keanekaragaman hayati (Freeman \& Rogers, 2003). Informasi tersebut memberikan dasar untuk studi terumbu karang dan pemantauan lingkungan yang harus dipertimbangkan ketika merencanakan suatu kawasan konservasi perairan dan pengelolaan sumber daya laut dan pesisir Gugusan Pulau Biawak yang berkelanjutan.

Studi ini mencoba melakukan pemetaan geomorfologi terumbu karang dan karakterisasi distribusi sedimen di Gugusan Pulau Biawak untuk mendukung kawasan konservasi perairan melalui integrasi analisis data citra satelit dan sedimen permukaan dasar laut. Oleh karena itu, tujuan dari penelitian ini adalah: 1) memetakan zona geomorfologi terumbu karang dan habitat bentik, dan 2) mendeskripsikan karakteristik sedimen dasar laut Gugusan Pulau Biawak dan faktor-faktor pengontrolnya. Informasi tersebut merupakan persyaratan dasar untuk manajemen perikanan dan pemantauan lingkungan (Diaz et al., 2004).

\section{METODE PENELITIAN}

\section{Lokasi Penelitian}

Secara geologi, Gugusan Pulau Biawak terletak di Paparan Sunda (Sunda Shelf) yang merupakan bagian dari cekungan busur belakang (back-arc basin) lempeng benua yang luas dan dangkal (Jordan et al., 1993). Laut jawa yang sekarang kita lihat merupakan produk dari proses genang laut (transgresi) yang dimulai pada akhir zaman es maksimum sekitar \pm 18.000 tahun yang lalu (tyl). Air laut menggenangi Paparan Sunda termasuk gugusan pulau terumbu di Gugusan Pulau Biawak pada \pm 9.000 tyl dan mengawali fase terbentuknya koloni biota terumbu karang di Laut Jawa yang terus tumbuh hingga saat ini membentuk pulau-pulau terumbu (Solihuddin, 2014). Diawali oleh koloni alga dan moluska, kerangkanya membentuk substrat stabil, kemudian secara bertahap tumbuh koloni koral di perairan yang relatif jernih.

Secara oseanografi, pada saat musim barat (Desember hingga April), angin dari arah baratlaut menggerakan masa air Laut Jawa menuju ke arah timur melintasi Gugusan Pulau Biawak dengan kecepatan arus umumnya tidak lebih dari $40 \mathrm{~cm} / \mathrm{det}$. Sebaliknya, pada saat musim timur (Mei hingga Oktober, masa air dari arah timur didorong melintasi Laut Jawa dengan kecepatan arus melebihi $50 \mathrm{~cm} / \mathrm{det}$ (Gordon et al., 2010; Ray et al., 2005). Sistem angin musim dua arah tersebut berpengaruh terhadap tinggi gelombang di Gugusan Pulau Biawak dan sekitarnya dengan ketinggian mencapai 0,5-0,8 $\mathrm{m}$ dan berpengaruh secara signifikan terhadap bentuk orientasi pulau-pulau di Gugusan Pulau Biawak yang relatif memanjang timur-barat. Letaknya yang dikelilingi oleh daratan utama Gugusan Pulau Indonesia seperti Pulau Jawa, Kalimantan, dan Sumatra, Gugusan Pulau Biawak berada di lingkungan yang relatif aman dan terlindungi dari badai dan gelombang laut tinggi.

\section{Citra Satelit dan Pemrosesan Data}

Penelitian ini menggunakan citra satelit multispektral Sentinel-2A Level 1C tanggal akuisisi 16 Juli 2018 yang diunduh secara gratis melalui arsip Pusat Data Sains dan Observasi Sumber Daya Bumi, Survey Geologi Amerika (www.earthexplorer.usgs), diakses pada April 2019. Pemilihan citra satelit didasarkan pada visibilitas terbaik yang tersedia dan perairan yang relatif jernih. Koreksi geometrik citra merupakan langkah awal (pra-pengolahan) yang dilakukan menggunakan sistem koordinat geografis dan datum World Geodetic System 1984 (WGS 1984). Teknik digitasi pada monitor (on screen digitation) dari Harris \& Vlaswinkel (2008) digunakan untuk memetakan zona geomorfologi terumbu karang termasuk lereng (reef slope), puncak (reef crest), rataan (reef flat), laguna (lagoon), pulau pasir (sand cay), dan lainnya. Sedangkan tiga band (kanal) spektral citra Sentinel, yaitu band $2(0,45$ - 0,52 $\mu \mathrm{m}$; biru), band

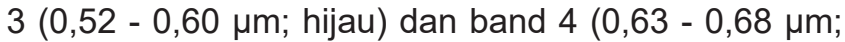
merah) dengan resolusi spasial 10 meter digunakan untuk memetakan distribusi habitat bentik termasuk koral, lamun, algae, sedimen, dan lainnya didukung dengan data pengamatan lapangan mengikuti alur kerja Solihuddin et al. (2019).

Daerah yang tidak termasuk ke dalam area pemetaan dipotong untuk mengurangi variabilitas kelas spektral dan mengurangi distorsi saat dilakukan klasifikasi (Kaczmarek et al., 2010). Pengelompokkan distribusi habitat bentik ke dalam kelas yang berbeda menggunakan teknik klasifikasi digital tanpa pengawasan (unsupervised classification) pada program ERDAS ER Mapper dan disimpan dalam bentuk file vektor untuk pemrosesan layout menggunakan program ArcGIS. Semua piksel dengan karakteristik spektral yang sama secara otomatis akan dikelompokkan ke dalam kelas habitat bentik tertentu.

\section{Uji Akurasi}

Pengujian akurasi hasil klasifikasi citra menggunakan matriks akurasi keseluruhan (overall accuracy) yang mencerminkan akurasi keseluruhan dalam peta sebagaimana ditentukan oleh perhitungan piksel yang diklasifikasikan dengan benar. Akurasi keseluruhan $(\%)=$ (jumlah piksel yang diklasifikasikan dengan benar/jumlah total pembagian kelas geomorfologi) x 100. Hasil dari matriks akurasi keseluruhan memberikan indikasi bahwa piksel dari citra Sentinel yang diklasifikasi telah mewakili habitat yang sebenarnya, sebagaimana hasil pengamatan 
dan pengambilan sampel langsung di lapangan.

\section{Pengambilan Sampel dan Analisis Sedimen}

Karakteristik dan komposisi sedimen permukaan Gugusan Pulau Biawak diamati secara langsung di lapangan dengan pengambilan sampel dilakukan secara random yang dianggap mewakili karakteristik sedimen Gugusan Pulau tersebut. Sedimen di Pulau Candikian tidak diambil karena kesulitan dalam aksesibilitas dan dianggap tidak berbeda secara signifikan dengan sedimen di Pulau Biawak dan Pulau Gosong. Karakteristik sedimen permukaan diamati secara visual selama survey pada April 2019 melalui snorkeling dan sampelnya diambil menggunakan wadah untuk meminimalisasi kehilangan sedimen berbutir halus. Kode pengambilan sampel diberikan label SB dan AB untuk sampel yang diambil di Pulau Biawak dan label SG untuk sampel yang diambil di Pulau Gosong. Secara total, 11 sampel sedimen telah diambil dan dilakukan analisis besar butir dan komposisinya.

Masing-masing sampel seberat 100 gram kemudian dicuci, dikeringkan, dan diayakmenggunakan seperangkat alat saringan seive shaker (masingmasing diameter saringan disamakan dengan batas ukuran butir Udden-Wentworth). Kelompok tekstur sedimen ditentukan mengikuti klasifikasi diagram segitiga Folk (1954). Program GRADISTAT dari Blott \& Pye (2001) digunakan untuk mendapatkan parameter statistik butiran sedimen termasuk besar butir rata-rata, standar deviasi, kemiringan, dan kurtosis. Persentase bioklastik sedimen (seperti echinodermata, Halimeda, foraminifera, ganggang merah, karang, dan moluska), agregat, spikula, dan fragmen batuan dikarakterisasi menggunakan mikroskop mengikuti panduan yang dijelaskan dalam Mazzullo et al. (1988).

\section{HASIL DAN PEMBAHASAN}

\section{Matriks Akurasi}

Penilaian akurasi pemetaan geomorfologi terumbu karang dan habitat bentik di Gugusan Pulau Biawak menggunakan proses matriks akurasi keseluruhan yang mencerminkan keseluruhan kesepakatan dalam peta sebagaimana ditentukan oleh titik hitungan piksel yang diklasifikasikan dengan benar dan diperoleh kisaran akurasi antara $57 \%$ dan $64 \%$ (Tabel 1).

\section{Geomorfologi Terumbu Karang dan Habitat Bentik Pulau Biawak}

Pulau Biawak merupakan pulau terumbu berbentuk lonjong (ovoid) menyerupai bulat telur berorientasi relatif baratlaut-tenggara dengan sumbu panjang $\pm 2,5 \mathrm{~km}$ dan sumbu pendek $\pm 1,3 \mathrm{~km}$ (Gambar 2). Pulau Biawak menjulang dengan curam ke permukaan dari dasar laut pada kedalaman $\sim 40 \mathrm{~m}$ (Gambar 3). Bagian dasar dari pulau terumbu tersebut diinterpretasi sama dengan bagian dasar pulau terumbu di Gugusan Pulau Seribu, Jakarta yaitu batulanau yang merupakan daratan pada Zaman Plistosen (1,8 juta11.700 tyl) (Ongkosongo, 1989).

Pulau terumbu dengan endapan pasir di bagian tengah (sand cay) ditumbuhi vegetasi mulai dari pohon waru, ketapang, hingga mangrove. Bagian rataan terumbu pada zona intertidal (pasang tertinggisurut terendah), ditutupi oleh pasir karbonat dengan pecahan koral (coral shingle). Bagian terumbu yang menghadap ke energi gelombang tinggi (windward) berada pada sisi baratlaut, sedangkan bagian terumbu yang relatif terlindungi (leeward) berada pada sisi tenggara. Koral hidup sangat jarang dijumpai pada bagian rataan terumbu. Algae hijau jenis Halimeda sp. merupakan koloni utama pada rataan terumbu bersama dengan alga coklat (Sargassum $s p$.). Rataan terumbu memiliki lereng yang relatif datar dan menurun secara gradual ke arah laut dibatasi oleh pecahan koral dan algae yang telah mengeras (encrusting coralline algae) pada bagian puncak terumbu (reef crest). Koral hidup banyak dijumpai di bagian lereng terumbu (reef slope) terutama di sisi baratlaut dengan dominasi koral bercabang dari jenis Acroporids. Mangrove dari jenis Rhizophora sp. dan Avicenia sp. tumbuh pada substrat pasir dan fragmen koral di bagian baratdaya pulau terutama pada alur anak sungai yang mengalirkan air tawar. Tumbuhnya mangrove di pulau ini berkontribusi terhadap pertumbuhan pulau, karena mangrove memfasilitasi akumulasi sedimen baru di sepanjang tepian pulau.

Table 1. Matriks akurasi keseluruhan tiap kelas geomorfologi dan habitat bentik hasil perbandingan klasifikasi citra dan pengamatan lapangan

\begin{tabular}{lllllllll}
\hline Pulau & \multicolumn{9}{c}{ Kelas (\%) } & \multirow{2}{*}{ Akurasi keseluruhan } \\
\cline { 2 - 6 } & RT+P & RT+H & \multicolumn{1}{c}{ RT+KA } & RT+PK & PT+PK & PT+KA & LT+KH & \\
\hline Biawak & 8,7 & 8,6 & 5,6 & 7,4 & 8,9 & 9,5 & 9,1 & $57,8 \%$ \\
Gosong & 9,5 & 7,5 & 8,7 & 9,6 & 8,3 & 8,1 & 9,5 & $61,2 \%$ \\
Candikian & 9,8 & 8,2 & 9,2 & 9,3 & 8,7 & 9,5 & 9,9 & $64,6 \%$
\end{tabular}

Ket: $\mathrm{RT}+\mathrm{P}=$ rataan terumbu+pasir, $\mathrm{RT}+\mathrm{H}=$ rataan terumbu+Halimeda, $\mathrm{RT}+\mathrm{KA}=$ rataan terumbu+kalkareus algae, $\mathrm{RT}+\mathrm{PK}=$ rataan terumbu+pecahan koral, $\mathrm{PT}+\mathrm{PK}=$ puncak terumbu+pecahan koral, $\mathrm{PT}+\mathrm{KA}=$ puncak terumbu+kalkareus algae, $\mathrm{LT}+\mathrm{KH}=$ lereng terumbu+koral hidup. 


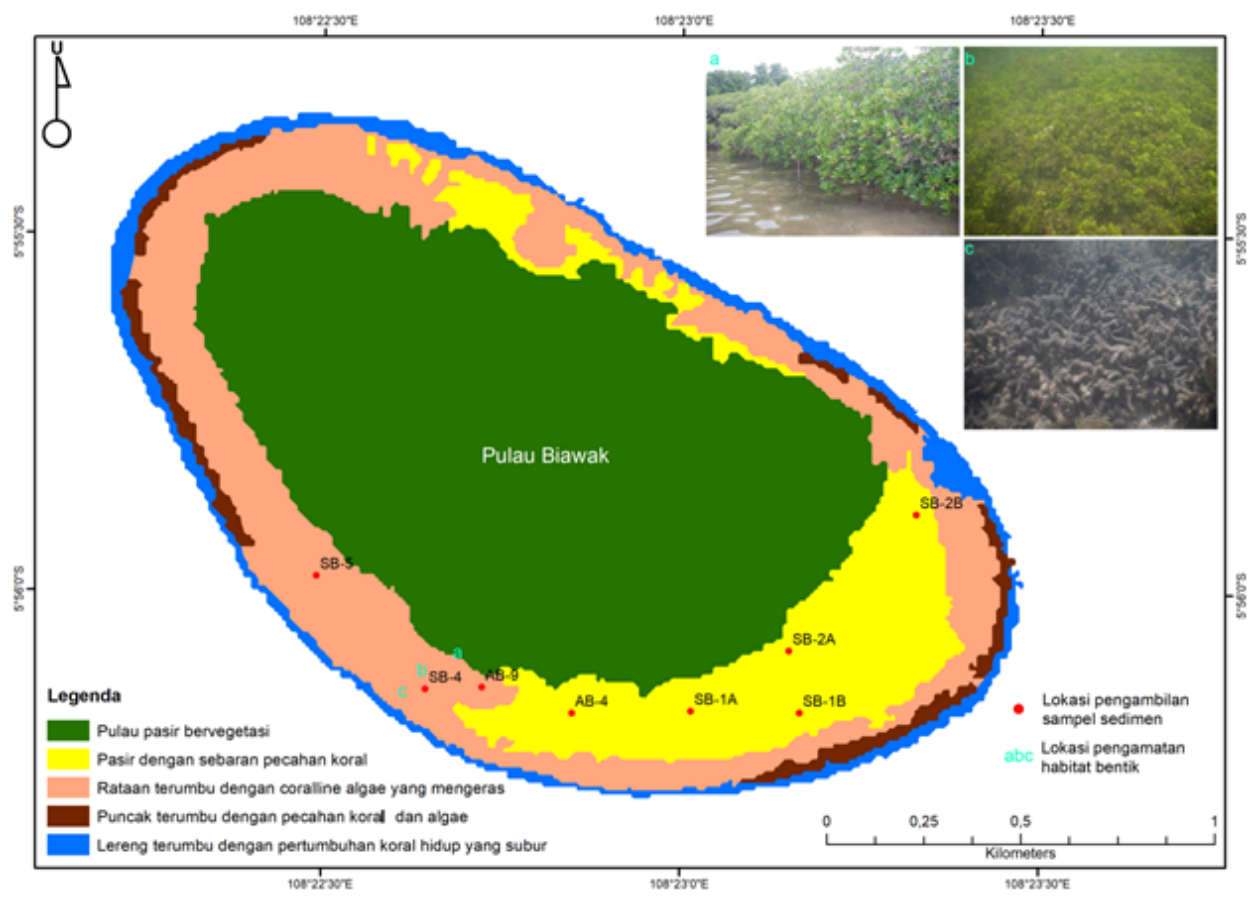

Gambar 2. Pembagian zona geomorfologi dan habitat bentik Pulau Biawak berdasarkan interpretasi citra Sentinel-2A dan pengamatan lapangan. Sisipan (insert) foto menunjukkan: a) mangrove jenis Avicennia sp., b) algae hijau jenis Halimeda sp., dan c) pecahan koral bercabang jenis Acropora $s p$.

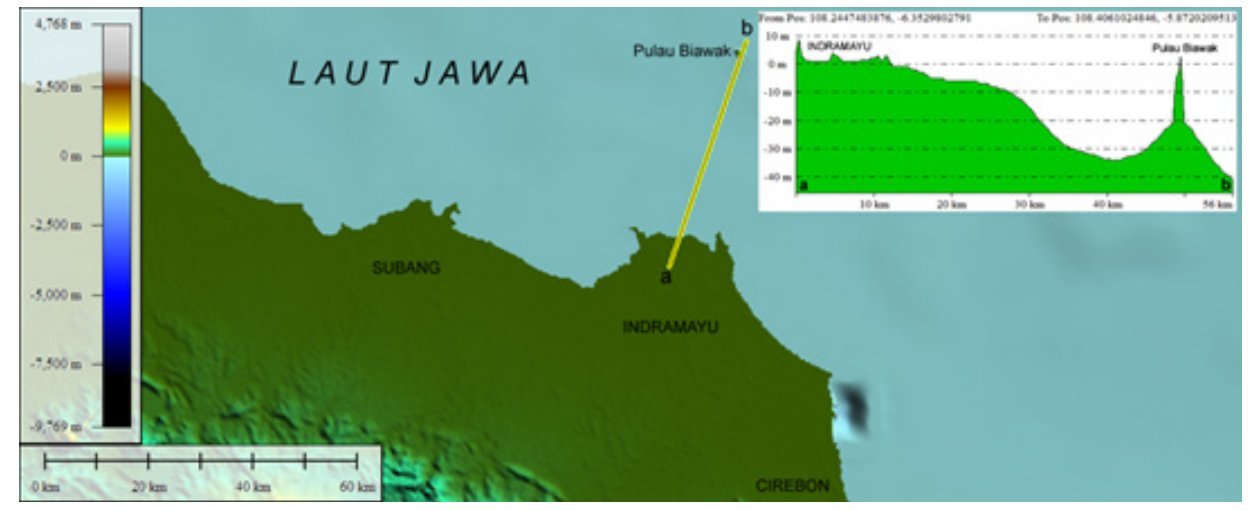

Gambar 3. Profil Pulau Biawak berjarak $\sim 50 \mathrm{~km}$ dari daratan Indramayu dan menjulang ke permukaan laut dari kedalaman $<40 \mathrm{~m}$.

\section{Pulau Gosong}

Selain Pulau Biawak, terdapat juga Pulau Gosong yang berjarak sekitar $8 \mathrm{~km}$ arah utara Pulau Biawak. Pulau ini juga merupakan pulau terumbu berbentuk cincin karang (atol) berorientasi relatif barat-timur dengan sumbu panjang sekitar $3,5 \mathrm{~km}$ dan sumbu pendek $\pm 1,3 \mathrm{~km}$. Di bagian tengah pulau terdapat laguna yang dalam $(\sim 25 \mathrm{~m})$, tersambung dengan lautan melalui kanal sempit di bagian selatan (Gambar 4). Terdapat pulau pasir yang sempit pada kedua pintu kanal. Sama halnya dengan P. Biawak, P. Gosong menjulang ke permukaan dari kedalaman laut sekitar $\sim 40 \mathrm{~m}$. Bagian rataan terumbu ditutupi oleh pasir karbonat dengan pecahan koral tersebar hampir di seluruh bagian rataan terumbu. Koral hidup banyak dijumpai pada bagian lereng terumbu (reef slope) sisi baratdaya dengan dominasi koral bercabang jenis Acropora formosa.

\section{Pulau Candikian}

Pulau Candikian adalah pulau paling luar terletak sekitar 7,5 km di sebelah timurlaut Pulau Gosong. Pulau ini muncul ke permukaan laut dari kedalaman sekitar $\sim 40 \mathrm{~m}$. Berbeda dengan Pulau Gosong, Pulau Candikian merupakan cincing karang (atol) berbentuk lonjong yang mengelilingi sepenuhnya laguna di bagian tengah (enclosed lagoon) dengan pulau pasir kecil (sand cay) diendapkan di atas pinggiran atol (atoll rim) dan terekspos pada saat pasang tinggi. Sumbu panjangnya memiliki panjang sekitar $3,6 \mathrm{~km}$, 


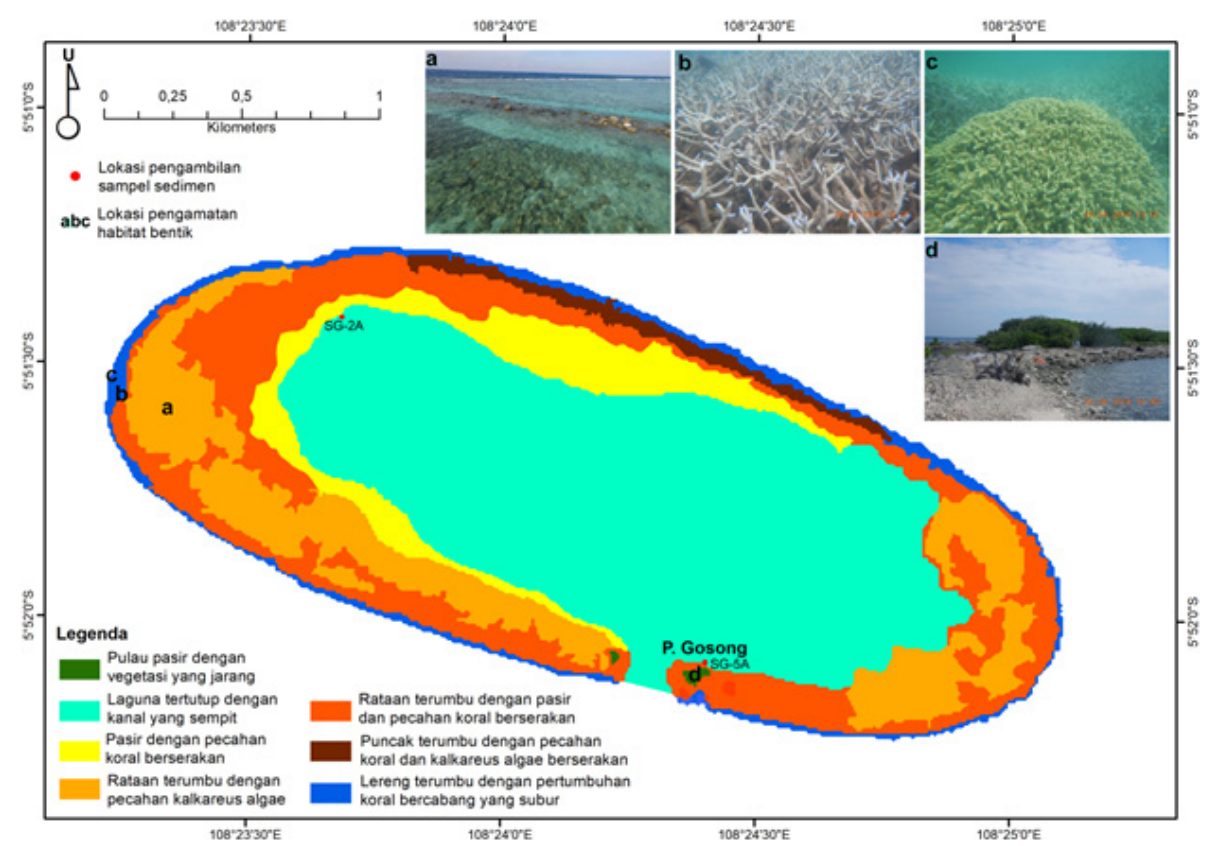

Gambar 4. Pembagian zona geomorfologi dan habitat bentik Pulau Gosong berdasarkan interpretasi citra Sentinel-2A dan pengamatan lapangan. Sisipan (insert) foto menunjukkan: a) Kalkareus algae, b) Acropora formosa, c) Acropora formosa dan Porites cylindrica, dan d) pulau pasir dengan vegetasi mangrove.

sementara sumbu pendeknya memiliki panjang kurang lebih $1,2 \mathrm{~km}$ dengan total luas sekitar $3 \mathrm{~km}^{2}$ (Gambar 5). Satu per tiga dari rataan terumbu karang ditutupi oleh koral gravel yang tererosi oleh gelombang, sementara dua per tiga bagian dalam rataan terumbu dipenuhi oleh karang mati dan beberapa tumpukan pasir (shoal). Pada rataan terumbu juga banyak dijumpai busut terumbu (reef knolls) dan atol mikro (microatolls) berukuran diameter $\sim 1 \mathrm{~m}$. Pulau ini muncul sebagian ke permukaan saat air surut dan seluruhnya terendam pada saat air pasang. Koloni koral tumbuh subur di bagian lereng dengan kemiringan sekitar $30^{\circ}$ yang terus menurun hingga kedalaman $40 \mathrm{~m}$.

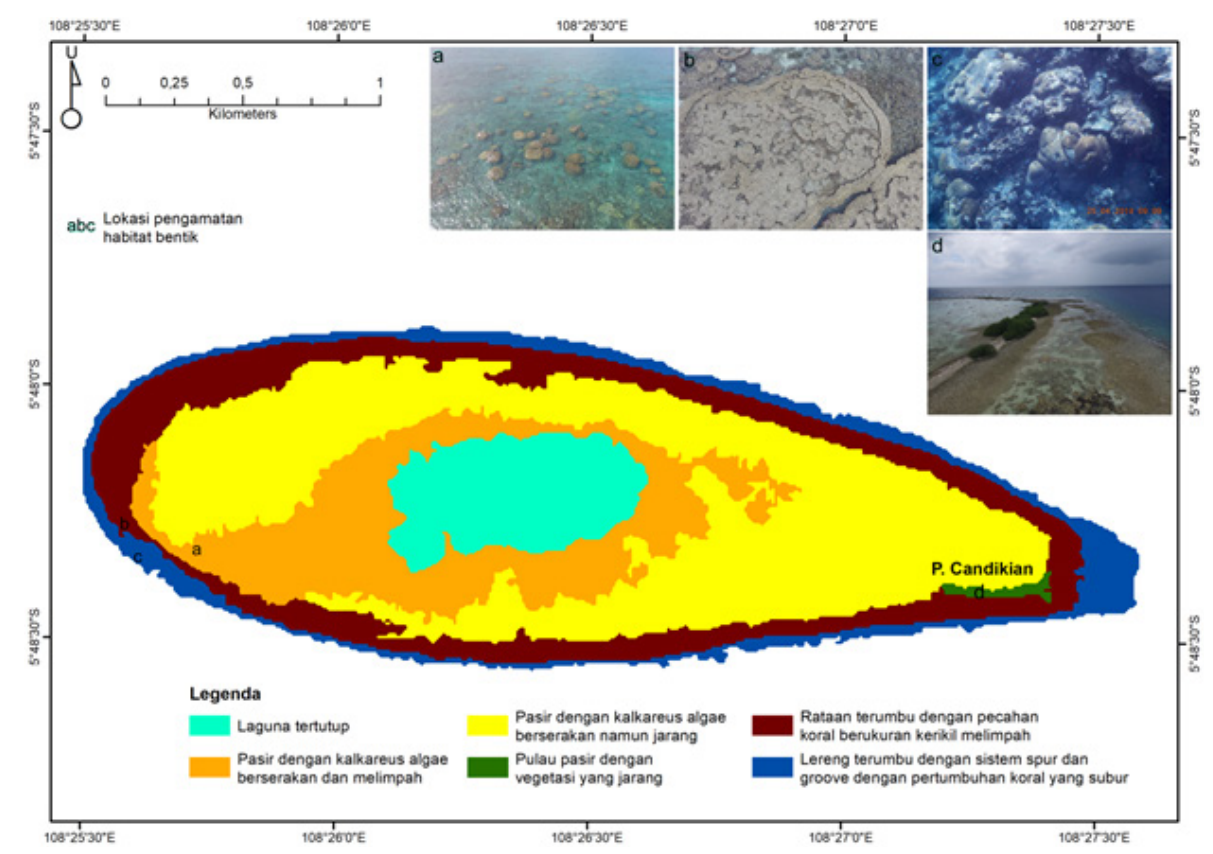

Gambar 5. Pembagian zona geomorfologi dan habitat bentik Pulau Candikian berdasarkan interpretasi citra Sentinel-2A dan pengamatan lapangan. Sisipan (insert) foto menunjukkan: a) Busut terumbu (Reef knoll), b) Atol mikro (microatoll), c) koral masif dengan kalkareus algae, d) Pulau pasir (sand cay) ditumbuhi vegetasi mangrove. 


\section{Tekstur dan Komposisi Sedimen}

Tekstur sedimen permukaan terumbu karang di Gugusan Pulau Biawak umumnya merupakan pasir kasar dengan pilahan (sorting) terpilah buruk (Tabel 2). Pasir kasar dengan persentase gravel (kerikil) tertinggi (22\%) terdapat pada sampel AB-4 (Pulau Biawak) dan pada habitat bentik endapan pasir dengan sebaran pecahan koral. Sedangkan pasir halus dengan persentase kandungan lumpur (mud) tertinggi (54\%) terdapat pada sampel SG-4A (Pulau Gosong) dan pada habitat bentik endapan pasir dengan sebaran pecahan koral. Dengan demikian, tidak terdapat pola sebaran tekstur sedimen tertentu sehubungan dengan perubahan zona geomorfologi dan habitat bentik. Artinya, ukuran besar butir sedimen bervariasi dan bercampur di suatu zona geomorfologi dan habitat bentik tertentu.

Komposisi sedimen Gugusan Pulau Biawak didominasi oleh komponen bioklastik termasuk koral, moluska, foraminifera, Halimeda, alga merah, dan echinodermata. Sedangkan fragmen batuan, agregat, dan spikula, meskipun ada, jumlahnya hanya minor. Karang dan moluska merupakan komponen bioklastik tertinggi pertama dan kedua yang kandungan tertingginya masing-masing mencapai $68 \%$ dan $40 \%$ (Tabel 3, Gambar 6). Sedangkan komponen bioklastik lainnya termasuk foraminifera, Halimeda, alga merah, dan echinodermata kandungan tertingginya masing- masing mencapai 15\%, 14\%, 7\%, dan 6\% (Tabel 3). Proporsi tertinggi fragmen lithic, spikula, dan agregat masing-masing adalah 3\%, 3\%, dan 2\% (Gambar 6).

\section{Karakteristik Terumbu Karang Gugusan Pulau Biawak}

Terumbu karang yang terbentuk dan berkembang di Gugusan Pulau Biawak memiliki kelimpahan dan keanekaragaman hayati cukup tinggi. Namun, hingga saat ini survei terkait kelimpahan jenis dan keanekaragaman hayati terumbu karang di Gugusan Pulau Biawak masih terbatas dilakukan. Menurut survei yang dilakukan oleh Purba dan Harahap (2013), setidaknya ada 7 jenis koral scleractinian di Gugusan Pulau Biawak diantaranya Acropora digitata, Acropora tabulate, Acropora formosa, Heliopora, Acropora millepora, Fungia, dan P. foliosa. Sebagai perbandingan, kami mengusulkan komunitas karang berdasarkan pengamatan di lapangan termasuk: $A$. formosa, A. hyacinthus, A. grandis, A. palifera, Porites cylindrica, Porites $s p$, Favites sp, Faviidae, Montipora sp, Goniastrea, Fungia, Turbinaria, Platygyra, dan Symphyllia (Gambar 7).

Berdasarkan pembagian dasar jenis terumbu karang dari Tomascik et al. (1997), terumbu di Gugusan Pulau Biawak masuk ke dalam jenis terumbu karang platform (P. Biawak) dan karang cincin (P. Gosong dan Candikian), menunjukkan beberapa karakteristik,

Table 3.

Hasil analisis besar butir dan parameter statistik butiran sedimen gugusan Pulau Biawak, Indramayu Jawa Barat

\begin{tabular}{|c|c|c|c|c|c|c|c|c|c|}
\hline \multirow[t]{2}{*}{ Kode Sampel } & \multicolumn{3}{|c|}{$\begin{array}{l}\text { Besar butir sedimen } \\
(\%)\end{array}$} & \multicolumn{4}{|c|}{$\begin{array}{l}\text { Parameter statistik butiran } \\
\text { Metode Folk \& Ward (mm) }\end{array}$} & \multirow[t]{2}{*}{$\begin{array}{l}\text { Tekstur sedimen } \\
\text { (Folk, 1954) }\end{array}$} & \multirow[t]{2}{*}{ Habitat bentik } \\
\hline & Gravel & Sand & Mud & Mean & Sorting & Skewn & sKurtosis & & \\
\hline SB-1A & 6 & 76 & 18 & 312,85 & 4,40 & $-0,08$ & 1,27 & Pasir sedang & $\begin{array}{l}\text { Endapan pasir dengan } \\
\text { sebaran pecahan koral }\end{array}$ \\
\hline SB-1B & 13 & 71 & 16 & 455,93 & 4,37 & $-0,12$ & 1,06 & Pasir sedang & $\begin{array}{l}\text { Endapan pasir dengan } \\
\text { sebaran pecahan koral }\end{array}$ \\
\hline SB-2A & 18 & 77 & 6 & 800,73 & 2,88 & $-0,38$ & 1,08 & Pasir kasar & $\begin{array}{l}\text { Endapan pasir dengan } \\
\text { sebaran pecahan koral }\end{array}$ \\
\hline SB-2B & 2 & 91 & 7 & 576,48 & 2,96 & $-0,36$ & 1,05 & Pasir kasar & $\begin{array}{l}\text { Endapan pasir dengan } \\
\text { sebaran pecahan koral }\end{array}$ \\
\hline SB-4 & 12 & 84 & 4 & 655,66 & 2,46 & 0,01 & 1,00 & Pasir kasar & $\begin{array}{l}\text { Koral dan algae yang } \\
\text { sudah mengeras }\end{array}$ \\
\hline SB-5 & 11 & 85 & 3 & 561,96 & 2,55 & 0,08 & 0,95 & Pasir kasar & $\begin{array}{l}\text { Koral dan algae yang } \\
\text { sudah mengeras }\end{array}$ \\
\hline AB-4 & 22 & 67 & 11 & 549,44 & 4,09 & $-0,11$ & 0,96 & Pasir kasar & $\begin{array}{l}\text { Endapan pasir dengan } \\
\text { sebaran pecahan koral }\end{array}$ \\
\hline AB-9 & 10 & 75 & 15 & 427,32 & 4,06 & $-0,14$ & 1,25 & Pasir sedang & $\begin{array}{l}\text { Koral dan algae yang } \\
\text { sudah mengeras }\end{array}$ \\
\hline SG-2A & 0 & 76 & 24 & 183,17 & 4,10 & $-0,36$ & 1,57 & Pasir halus & $\begin{array}{l}\text { Endapan pasir dengan } \\
\text { sebaran pecahan koral }\end{array}$ \\
\hline SG-4A & 0 & 46 & 54 & 68,56 & 4,77 & $-0,26$ & 0,82 & Pasir halus & $\begin{array}{l}\text { Endapan pasir dengan } \\
\text { sebaran pecahan koral }\end{array}$ \\
\hline SG-5A & 0 & 92 & 8 & 409,85 & 2,76 & $-0,17$ & 1,36 & Pasir sedang & $\begin{array}{l}\text { Endapan pasir dengan } \\
\text { sebaran pecahan koral }\end{array}$ \\
\hline
\end{tabular}


Table 3.

Komposisi sedimen permukaan gugusan Pulau Biawak, Indramayu Jawa Barat

\begin{tabular}{|c|c|c|c|c|c|c|c|c|c|c|}
\hline \multirow[t]{2}{*}{ No } & \multirow{2}{*}{ Kode Sampel } & \multicolumn{5}{|c|}{ Komponen bioklastik } & \multirow[b]{2}{*}{$\begin{array}{l}\text { Molus } \\
\text { ka }\end{array}$} & \multirow[t]{2}{*}{ Agregat } & \multirow[t]{2}{*}{ Spikula } & \multirow{2}{*}{$\begin{array}{l}\text { Fragmen } \\
\text { Lithic }\end{array}$} \\
\hline & & $\begin{array}{l}\text { Echino } \\
\text { dermata }\end{array}$ & $\begin{array}{l}\text { Hali } \\
\text { meda }\end{array}$ & $\begin{array}{l}\text { Forami } \\
\text { nifera }\end{array}$ & $\begin{array}{l}\text { Alga } \\
\text { merah }\end{array}$ & koral & & & & \\
\hline 1 & SB-1A & $1 \%$ & $0 \%$ & $3 \%$ & $0 \%$ & $59 \%$ & $33 \%$ & $1 \%$ & $0 \%$ & $0 \%$ \\
\hline 2 & SB-1B & $1 \%$ & $2 \%$ & $4 \%$ & $1 \%$ & $52 \%$ & $40 \%$ & $0 \%$ & $0 \%$ & $0 \%$ \\
\hline 3 & SB-2A & $6 \%$ & $2 \%$ & $5 \%$ & $3 \%$ & $48 \%$ & $334 \%$ & $0 \%$ & $0 \%$ & $0 \%$ \\
\hline 4 & SB-2B & $1 \%$ & $2 \%$ & $6 \%$ & $7 \%$ & $68 \%$ & $12 \%$ & $1 \%$ & $0 \%$ & $0 \%$ \\
\hline 5 & SB-4 & $1 \%$ & $9 \%$ & $5 \%$ & $1 \%$ & $67 \%$ & $16 \%$ & $2 \%$ & $0 \%$ & $3 \%$ \\
\hline 6 & SB-5 & $3 \%$ & $9 \%$ & $6 \%$ & $4 \%$ & $54 \%$ & $22 \%$ & $2 \%$ & $0 \%$ & $5 \%$ \\
\hline 7 & AB-4 & $6 \%$ & $3 \%$ & $6 \%$ & $2 \%$ & $44 \%$ & $37 \%$ & $0 \%$ & $3 \%$ & $2 \%$ \\
\hline 8 & AB-9 & $2 \%$ & $14 \%$ & $8 \%$ & $2 \%$ & $49 \%$ & $22 \%$ & $0 \%$ & $3 \%$ & $3 \%$ \\
\hline 9 & SG-2A & $2 \%$ & $1 \%$ & $1 \%$ & $2 \%$ & $34 \%$ & $57 \%$ & $0 \%$ & $0 \%$ & $0 \%$ \\
\hline 10 & SG-4A & $3 \%$ & $0 \%$ & $15 \%$ & $5 \%$ & $23 \%$ & $55 \%$ & $0 \%$ & $0 \%$ & $1 \%$ \\
\hline 11 & SG-5A & $3 \%$ & $1 \%$ & $3 \%$ & $1 \%$ & $65 \%$ & $26 \%$ & $0 \%$ & $0 \%$ & $0 \%$ \\
\hline
\end{tabular}

(Sumber: pengolahan data, 2019)

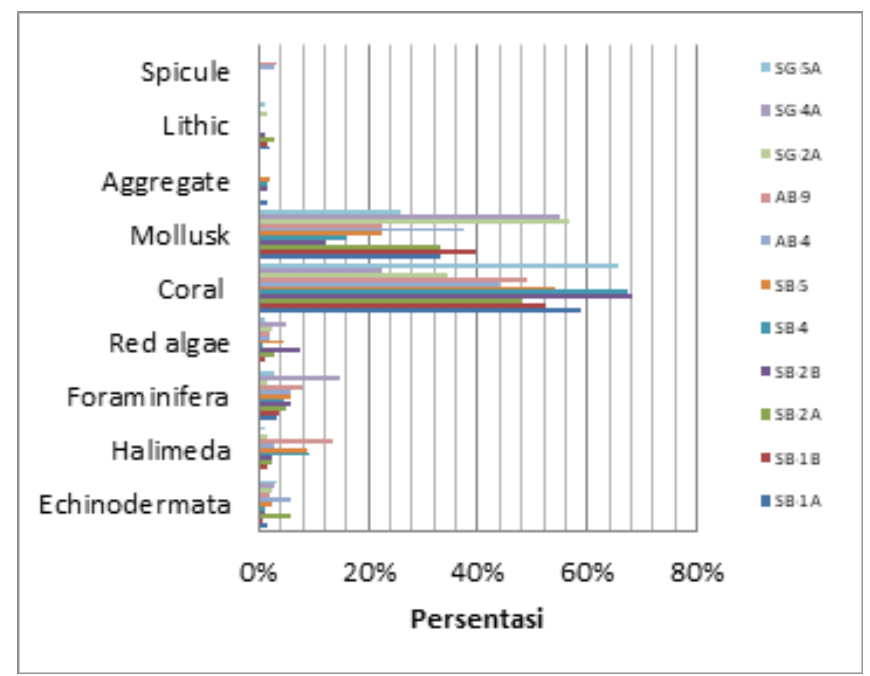

Gambar 6. Diagram batang untuk komposisi sedimen Gugusan Pulau Biawak menunjukkan komposisi bioklastik, agregat, spikula, dan fragmen lithic.

diantaranya: 1) Pulau Biawak, Gosong, dan Candikian merupakan grup 3 terumbu karang lepas pantai yang tumbuh di Laut Jawa pada bagian tengah Paparan Sunda dan berkembang di atas subtrat batu berumur Plistosen, 2) Ketiganya hampir memiliki dimensi, bentuk, orientasi, jarak antara, dan muncul di permukaan laut dari kedalaman $\pm 40 \mathrm{~m}$ (Gambar 8), 3) Pulau pasir yang luas ditumbuhi berbagai macam vegetasi pada Pulau Biawak, namun hanya pulau pasir yang kecil dan sempit ditumbuhi sedikit vegetasi pada Pulau Gosong dan Candikian, 4) Tidak terdapat morfologi laguna pada Pulau Biawak, namun hadir pada Pulau Gosong dan Candikian, 5) Bagian lereng terumbu (forereef slope) menurun secara tajam setelah puncak terumbu dengan kemiringan $15-30^{\circ}$ di bagian atas lereng terumbu dan cenderung menurun tajam mendekati vertikal di bagian tengah hingga ke bagian dasar, 6) Koral hidup sangat jarang dijumpai pada bagian rataan terumbu, sedangkan fragmen koral dan alga mengeras dominan hingga bagian puncak terumbu, 7) Bagian lereng terumbu memiliki pertumbuhan terumbu karang yang subur dengan dominan koral bercabang Acropora pada Pulau Biawak dan Gosong, 8) Pada rataan terumbu Pulau Candikian banyak dijumpai busut terumbu (reef knolls) dan atol mikro (microatolls) berukuran diameter $\sim 1 \mathrm{~m}$.

\section{Karakteristik Sedimen dan Faktor Pengontrolnya}

Tekstur sedimen di Gugusan Pulau Biawak sebagian besar adalah sedimen berbutir kasar dengan pilahan terpilah buruk. Artinya, tidak terdapat perubahan signifikan dalam tekstur sedimen karena perubahan geomorfologi dan habitat bentik menunjukkan dominasi pasir bertekstur kasar. Selain itu, pilahan buruk menunjukkan energi penggerak sedimen tersebut tergolong rendah. Hal tersebut menunjukkan bahwa sedimen pada rataan terumbu di Gugusan Pulau Biawak sebagian besar berasal dari erosi terumbu karang dan sebagian besar terdiri dari pasir karbonat bioklastik, agregat, fragmen batuan, dan 


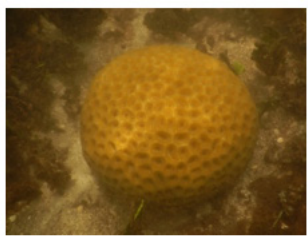

Favites $s p$

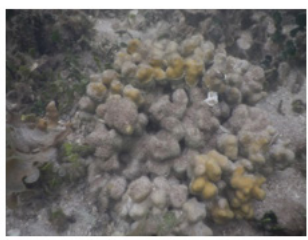

A.Palifera

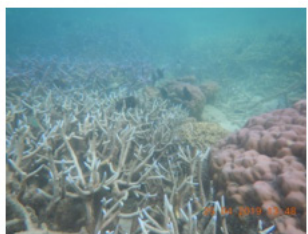

A.Formosa+porites

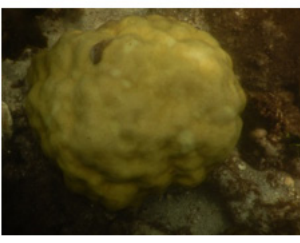

Porites $s p$

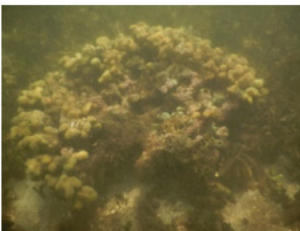

Stylophora pistillata

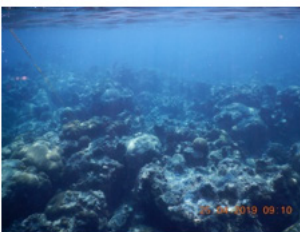

Faviidae

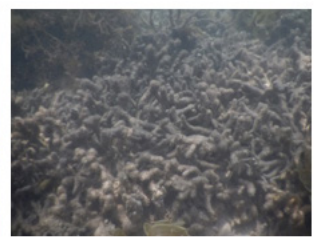

Acroporidae

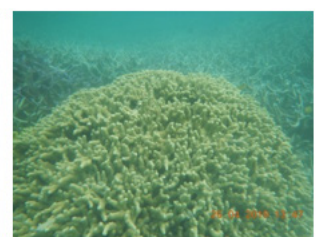

Porites cylindrica

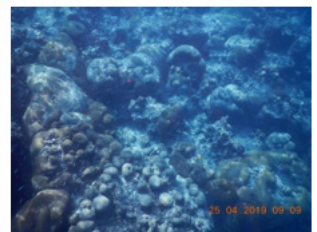

Faviidae

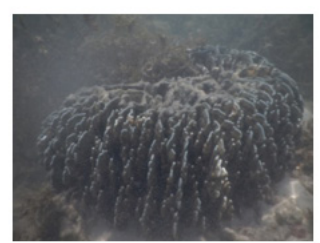

A.Palifera

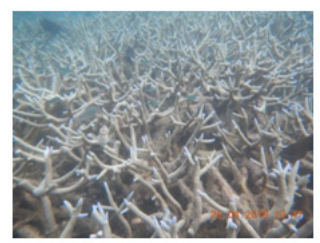

A.Formosa

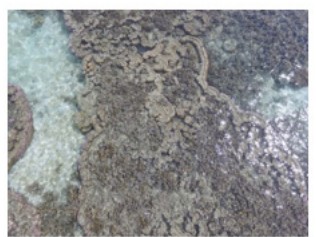

Porites

Gambar 7. Jenis koral scleractinian di gugusan Pulau Biawak, Indramayu menunjukkan jenis koral Favites $s p$, Porites sp, Acroporidae, A. palifera, Stylophora pistillata, Porites cylindrica, A. formosa, dan koloni Faviidae.

spikula. Karakteristik tersebut sesuai dengan Tomascik et al. (1997), Wilson (2002, 2012), dan Madden et al. (2013) yang menyoroti dominasi kumpulan bioklastik dalam simpanan karbonat Indonesia.

Koral merupakan kontributor utama dalam pasir karbonat di Gugusan Pulau Biawak bersama dengan komponen bioklastik lainnya seperti moluska, foraminifera, Halimeda, alga merah, dan echinodermata (Tabel 2). Proporsi agregat, spikula, dan fragmen batuan, meskipun ada, tidak terlalu signifikan, menunjukkan kurangnya input sungai ke lingkungan terumbu karang di Gugusan Pulau Biawak. Kondisi tersebut sesuai dengan Spalding \& Grenfell (1997) serta Vescei (2004), yang menyampaikan bahwa koral merupakan komponen utama dalam lingkungan karbonat neritik. Tekstur dan komposisi sedimen di Gugusan Pulau Biawak mirip atau sebanding dengan tekstur dan komposisi sedimen di Gugusan Pulau Seribu, DKI Jakarta (Utami et al., 2018) dan Gugusan Pulau Karimunjawa, Jawa Tengah (Solihuddin et al.,2019).

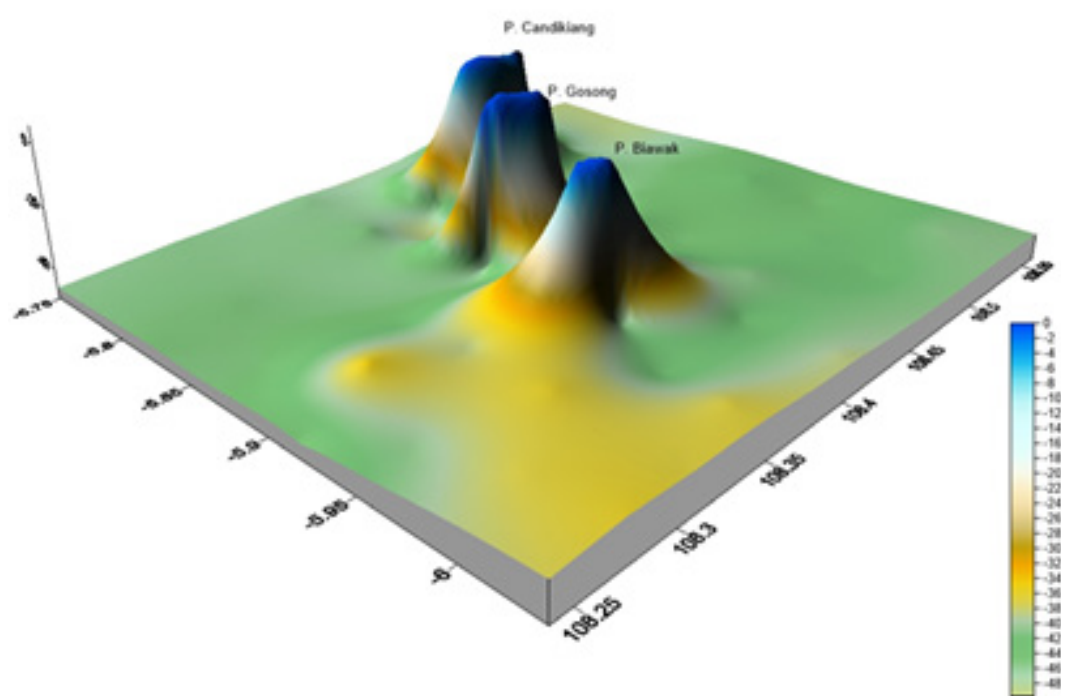

Gambar 7. Penampang 3 dimensi Gugusan Pulau Biawak menjulang dari dasar laut $<40 m$ (Sumber: pengolahan data, 2019). 


\section{KESIMPULAN}

Pengetahuan tentang geomorfologi terumbu karang dan asosiasi habitat bentik sangat penting dalam penentuan zona konservasi dan keperluan pengelolaan lainnya. Gugusan Pulau Biawak memiliki potensi pariwisata bahari dengan nilai ekonomi, ekologi dan edukasi yang tinggi mengingat jaraknya yang tidak terlalu jauh dari Kota Indramayu. Geomorfologi dan habitat bentik terumbu karang Gugusan Pulau Biawak menunjukkan kondisi umum terumbu karang di kawasan Laut Jawa diantaranya berbentuk terumbu platform dan cincin karang, menjulang ke permukaan laut dari kedalaman $\pm 40 \mathrm{~m}$, berorientasi relatif barattimur, sisi barat terpapar terhadap energi gelombang tinggi dan sisi timur relatif lebih terlindungi, bagian lereng terumbu menurun secara tajam setelah puncak terumbu, koral hidup sangat jarang dijumpai pada bagian rataan terumbu sedangkan bagian lereng terumbu memiliki pertumbuhan koral yang subur. Sedimen pada rataan terumbu di Gugusan Pulau Biawak sebagian besar berasal dari erosi terumbu karang di lingkungan perairan Gugusan Pulau Biawak itu sendiri dan sebagian besar terdiri dari pasir karbonat bioklastik, selain komposisi minor dari agregat, fragmen lithic, dan spikula. Upaya konservasi terumbu karang di Gugusan Pulau Biawak dan sekitarnya sangat penting untuk melindungi dan menjaga kelestarian terumbu karang serta keseimbangan lingkungan karena pencemaran lingkungan dan insiden kerusakan terumbu karang di kawasan ini utamanya disebabkan oleh faktor manusia (antropogenik).

\section{PERSANTUNAN}

Penelitian ini dibiayai oleh DIPA Pusat Riset Kelautan Badan Riset dan Sumber Daya Manusia Kementerian Kelautan dan Perikanan 2019. Kami sangat berterima kasih kepada Bapak Riyanto Basuki (Kepala Pusat Riset Kelautan 2017-2020), Triyono (Kepala Bidang Mitigasi, Adaptasi, dan Konservasi), Joko Hardono (Kepala Sub Bidang Konservasi). Ucapan terima kasih juga kami sampaikan kepada seluruh pihak yang terlibat dalam penelitian ini khususnya kepada anggota tim penelitian "Kajian Evaluasi Kawasan Konservasi Perairan Daerah Gugusan Pulau Biawak, Indramayu, Jawa Barat Berdasarkan Analisis Dinamika Lingkungan Perairan". Tubagus Solihuddin adalah kontributor utama dalam penulisan artikel ini.

\section{DAFTAR PUSTAKA}

Asriningrum, W. (2011). Reef morphology identification in Sikka, NTT using Landsat imagery. Journal of Indonesian Coral Reefs, 1, 48-54.

Blott, S.J., \& Pye, K. (2001). GRADISTAT: a grain size distribution and statistics package for the analysis of unconsolidated sediments. Earth surface processes and Landforms, 26 (11), 1237-1248.

Diaz, R. J., Solan, M., \& Valente, R.M. (2004). A review of approaches for classifying benthic habitats and evaluating habitat quality. Journal of Environmental Management, 73, 165-181.

Folk, R.L. (1954). The distinction between grain size and mineral composition in sedimentary-rock nomenclature. Journal of Geology, 62, 344-359.

Freeman, S.M., Rogers, S.I. (2003). A new analytical approach to the characterisation of macroepibenthic habitats: linking species to the environment. Estuarine, Coastal and Shelf Science, 56, 749-764.

Gordon, A.L., Sprintall, J., van Aken, H.M., Susanto, D., Vijffels, S., Molcard, R., Ffield, A., Pranowo ,W., \& Wirasantosa, S. (2010). The Indonesian throughflow during 2004-2006 as observed by the INSTANT program. Dynamics of Atmospheres and Oceans. 50, 115-128.

Harris, P.M., \& Vlaswinkel, B. (2008). Modern isolated carbonate platforms: templates for quantifying facies attributes of hydrocarbon reservoirs. In: Lukasik, J., Simo, T. (Eds.), Controls on Carbonate Platform and Reef Development. SEPM Special Publication, 89, pp. 323-341.

Jordan, C.F., Wharton, R.J., \& Cook, R.E. (1993). The sedimentology of Gugusan Pulau Seribu: A modern patch reef complex in the west Java Sea, Indonesia. In: Modern Carbonates and their Ancient Counterparts in Indonesia: A Guide to Interpreting and Understanding Carbonate Reservoirs. Indonesian Petroleum Association, Carbonate Seminar 9 May 1993, Jakarta, pp. 2.12.6.

Kaczmarek, S.E., Hicks, M.K., Fullmer, S.M., Steffen, K.L., \& Bachtel, S.L. (2010). Mapping facies distributions on modern carbonate platforms through integration of multispectral Landsat data, statistics-based unsupervised classifications, and surface sediment data. American Association of Petroleum Geologists Bulletin, 94, 1581-1606.

Madden, R.H.C., Wilson, M.E.J., \& O'Shea, M. (2013). Modern fringing reef carbonates from equatorial SE Asia: An integrated environmental, sediment and satellite characterisation study. Marine Geology, 344, 163-185.

Mazzullo, J., Graham, A.G., \& Braunstein, C. (1988). Handbook for Shipboard Sedimentologists. 
Ocean Drilling Program Technical Note No. 8.

Ongkosongo, O.S.R. (1989). Background information for the field trip to the Seribu Reefs, Indonesia. Short Course on Carbonate Sedimentology and Stratigraphy, 4-8 September 1989, Jakarta. Indonesian Petroleum Association.

Purba, N.P. \& Harahap, S.A. (2013). Pulau-pulau Kecil Indonesia Persfektif Kelautan. Edisi BiawakGosong-Candikian. Unpad press, 46 hal.

Ray, R.D., Egbert, G.D. \& Erofeeva, S.Y. (2005). A brief overview of tides in the Indonesian Seas. Oceanography, 18(4), 74-79.

Spalding, M.D. \& Grenfell, A.M. (1997). New estimates of global and regional coral reef areas. Coral Reefs, 16, 225-230.

Solihuddin, T., Utami, A.D., Salim, H.L., \& Prihantono, J. (2019). Sedimentary Environment of A Modern Carbonate Platform of Karimunjawa Islands, Central Java. Indonesian Journal on Geoscience, 6(1), 57-72.

Solihuddin, T. (2014). A Drowning Sunda Shelf Model during Last Glacial Maximum (LGM) and Holocene: A Review. Indonesian Journal on Geoscience, 1(2), 99-107.

Sunarto, Riyantini, I., Ihsan, A.Y.N., \& Harahap, S.A. (2013). Kajian Sumberdaya Kelautan Pulau Biawak dan Laut sekitarnya Kabupaten Indramayu Jawa Barat. Laporan Akhir Penelitian Unggulan Perguruan Tinggi (tidak dipublikasikan). FPIK Universitas Padjadjaran.

Tomascik, T., Mah, A.J., Nontji, A., \& Moosa, M.K. (1997). The ecology of Indonesian seas. Part 2, Periplus Editions.

Utami, D.A., Reuning, L., \& Cahyarini, S.Y. (2018). Satellite and Field Based Facies Mapping of Isolated Carbonate Platforms from the Kepulauan Seribu Complex, Indonesia. The Depositional Record, 4(2), 255-273. https://doi.org/10.1002/ dep2.47

Vecsei, A. (2004). A new estimate of global reefal carbonate production including the forereefs. Global and Planetary Change, 43, 1-18.

Wilson, M.E.J. (2002). Cenozoic carbonates in SE Asia: implications for equatorial carbonate development. Sedimentary Geology, 147, 295428.
Wilson, M.E.J. (2012). Equatorial carbonates: an earth systems approach. Sedimentology, 59, 1-31. 
Geomorfologi Terumbu Karang ...... Citra Satelit Dan Sedimen Permukaan (Solihuddin, T., et al.) 